\title{
Pengaruh Kesesuaian Kompensasi, Sistem Pengendalian Internal, Pemanfaatan Teknologi Informasi Dan Kompetensi Dengan Budaya Etis Organisasi Sebagai Variabel Moderating Terhadap Fraud \\ (Studi Empiris Pada Organisasi Perangkat Daerah Pemerintah Kota Jayapura)
}

\author{
Muhammad Rafli Djatmiko ${ }^{1}$ \\ rafli.jatmiko@gmail.com \\ Meinarni Asnawi ${ }^{1}$ \\ Rudiawie Larasati ${ }^{1}$ \\ Jurusan Akuntansi, Fakultas Ekonomi dan Bisnis Universitas Cenderawasih
}

\begin{abstract}
This research aims to provide empirical evidence to examine the effect of the suitability of compensation, internal control systems, the use of information technology and competence with organizational ethical culture as a moderating variable on fraud in the Local Government Organizations of the City of Jayapura.

This study uses primary data obtained by distributing questionnaires manually despite the covid-19 outbreak in Indonesia and globally to 70 respondents with a population of employees in the Regional Government Organization of the City of Jayapura. The data analysis method used is the Structure Equivalent Model (SEM) approach with a Partial Least Square sampling method, namely the sampling technique used to obtain samples with a rolling process from one respondent to another.

The results of this study show that the suitability of compensation, the use of information technology and competence does not affect fraud. The internal control system has a negative effect on fraud. Then the ethical culture of the organization does not moderate the suitability of compensation, the use of information technology for financial space, and then the ethical culture of the organization weakens the internal control system and competence against fraud.
\end{abstract}

Keywords: Fraud; Compensation Suitability; Internal Control System; Utilization of Information Technology and Competence.

\begin{abstract}
Abstrak
Penelitian ini bertujuan untuk memberikan bukti empiris menguji pengaruh kesesuaian kompensasi, sistem pengendalian internal, pemanfaatan teknologi informasi dan kompetensi sebagai dengan budaya etis organisasi sebagai variabel moderating terhadap Fraud pada Organisasi Perangkat Daerah Pemerintah Kota jayapura.

Penelitian ini menggunakan data primer yang diperoleh dengan menyebarkan kuesioner secara manual meskipun adanya wabah covid-19 di Indonesia dan global kepada 70 responden dengan populasi pegawai di Organisasi Perangkat Daerah Pemerintah Kota Jayapura. Metode analisis data yang digunakan adalah dengan pendekatan Structure Equatuin Model (SEM) dengan medote Partial Least Square sampling yaitu teknik sampel yang digunakan untuk memperoleh sampel dengan adanya proses bergulir dari satu responden ke responden lainnya.

Hasil penelitian ini adalah kesesuaian kompensasi, pemanfaatan teknologi informasi dan kompetensi tidak berpengaruh terhadap kecurangan (fraud). Sistem pengendalian internal berpengaruh negatif terhadap kecurangan (fraud). Kemudian budaya etis organisasi tidak memoderasi antara kesesuaian kompensasi, pemanfaatan teknologi informasi terhadap kecruangan dan berikutnya budaya etis organisasi memperlemah antara sistem pengendalian internal dan kompetensi terhadap kecurangan (fraud)
\end{abstract}

Kata Kunci : Fraud; Kesesuaian Kompensasi; Sistem Pengendalian Internal; Pemanfaatan Teknologi Informasi dan Kompetensi.

\section{Pendahuluan}

Di pemerintahan pusat maupun daerah untuk dapat memberikan pertanggungjawaban yang lebih 
transparan, efisiensi dan lebih akurat dibutuhkan laporan pertanggungjawaban kinerja keuangan kepada publik yaitu berupa laporan keuangan. Laporan keuangan merupakan salah satu bagian yang rentan terhadap fraud, seperti banyaknya kasus kecurangan (fraud) yang terjadi di berbagai negara termasuk di Indonesia (Fajarina, Wirda, 2012). Tindakan fraud yang dilakukan oleh birokrasi pemerintahan menimbulkan keprihatinan dan diperlukan perhatian khusus dari berbagai pihak, seperti Badan Pemeriksa Keuangan (BPK), Komisi Pemberantasan Korupsi (KPK), dan Badan Pengawasan Keuangan dan Pembangunan (BPKP) (Mudzakkir, 2005).

Kecurangan yang dilakukan disebabkan karena memiliki keinginan untuk dapat memaksimalkan keuntungan kelompok atau pribadi. Semakin berkembangnya fraud, pelaku-pelaku pun tidak terbatas pada golongan tingkat atas, namun banyak yang menyentuh lapisan pegawai tingat bawah. Banyak upaya pemerintah dalam menangani kasus fraud, namun belum adanya perubahan atau indikasi bahwa akan segera terhenti. Dengan berjalannya waktu tindakan kecurangan yang terungkap semakin banyak dan para pelakunya semakin kompleks dan banyak. Padahal laporan keuangan merupakan sumber informasi penting dalam organisasi sebagai alat komunikasi publik dan pengambilan keputusan (Adinda, 2015).

Fraud merupakan konsep pelanggaran yang memiliki konteks yang sangat luas. The Association of Certified Fraud Examiners (ACFE) membagi fraud dalam tiga jenis berdasarkan perbuatannya, yaitu: korupsi (corruption), penyalahgunaan asset (asset misappropriation), dan kecurangan dalam laporan keuangan (financial statement fraud). ACFE menyebutkan bahwa fraud merupakan perbuatan yang di anggap melawan sebuah hukum yang dilakukan dengan sengaja hanya untuk mencapai tujuan tertentu (manipulasi atau memberikan laporan yang salah terhadap pihak lain) yang juga dilakukan oleh kelompok ataupun individu baik itu dari dalam perusahaan maupun dari luar perusahaan hanya untuk mendapatkan atau memperoleh keuntungan pribadi ataupun kelompok yang secara tidak langsung atau langsung yang dapat merugikan pihak lain (Pratiwi, 2018).

Berdasarkan laporan Report To The Nations (RTTN) yang dikeluarkan oleh ACFE global diperoleh data dari negara-negara yang ada di kawasan Asia Pasific fraud yang paling banyak terjadi yaitu korupsi $51 \%$ dan di Indonesia terdapat 29 kasus fraud. Dari hasil survai oleh AFCE Indonesia sepanjang tahun 2016, fraud yang paling banyak terjadi di Indonesia adalah korupsi yaitu sebesar 67\% selanjutnya adalah penyalahgunaan asset $31 \%$ dan kemudian sebanyak $2 \%$ dalam kecurangan laporan keuangan (Association of Certified Fraud Examiners, 2017).

Beberapa penelitian sebelumnya telah dilakukan oleh banyak peneliti, terkait dengan faktorfaktor yang mempengaruhi kecurangan baik pada organisasi pemerintahan maupun organisasi sektor privat. Diantaranya yang dilakukan dalam penelitian Pratiwi (2018) yang meneliti pengaruh kesesuaian kompensasi, sistem pengendalian internal, pemanfaatan teknologi informasi, budaya etis organisasi dan kompetensi terhadap fraud. Hasilnya menyimpulkan bahwa apabila semakin baik sistem pengendalian internal maka tindakan seseorang untuk melakukan fraud semakin rendah dan apabila pemanfaatan teknologi informasi yang tinggi maka, dapat meminimalisirkan terjadinya suatu kecuarangan (fraud). Namun, kesesuaian kompensasi, budaya etis organisasi dan kompetensi tidak memiliki pengaruh terhadap kecurangan.

Penelitian ini dilakukan dengan menggali pandangan atau presepsi para pegawai di instansi pemerintah untuk mengetahui kecenderungan terjadinya kecurangan (fraud) dan juga faktor-faktor yang dapat mempengaruhinya. Faktor-faktor ini terdiri dari kesesuaian kompensasi, sistem pengendalian internal, pemanfaatan teknologi informasi, kompetensi dan budaya etis organisasi. Sehubungan dengan uraian yang telah di jelaskan di atas, maka peneliti akan melakukan penelitian dengan judul yaitu "Pengaruh Kesesuaian Kompensasi, Sistem Pengendalian Internal, Pemanfaatan Teknologi Informasi Dan Kompetensi Dengan Budaya Etis Orgnisasi Sebagai Variabel Moderating Terhadap Fraud". Dengan mereplikasi penelitian Pratiwi (2018) yang dilakukan pada Organisasi Perangkat Daerah (OPD) Kota Bandar Lampung dan OPD Kabupaten Pesawaran tahun 2018, yang membedakan penelitian ini adalah dengan menambahkan variabel moderasi pada budaya etis organisasi dan penempatan lokasi penelitian yang berbeda yaitu di Organisasi Perangkat Daerah (OPD) Pemerintah Kota Jayapura pada tahun 2020. 


\section{Kajian Pustaka}

\subsection{Fraud Pentagon Theory}

Fraud pentagon theory pertama kali disajikan oleh Crowe Howarth pada tahun 2011 sebagai penyempurnaan dari teori fraud triangle yang dikemukakan oleh Cressey tahun 1953. Crowe Howarth (2011) berpendapat bahwa untuk meningkatkan kemampuan mendeteksi fraud adalah dengan cara menambahkan elemen lain yaitu kompetensi (competence) dan arogansi (arrogance).

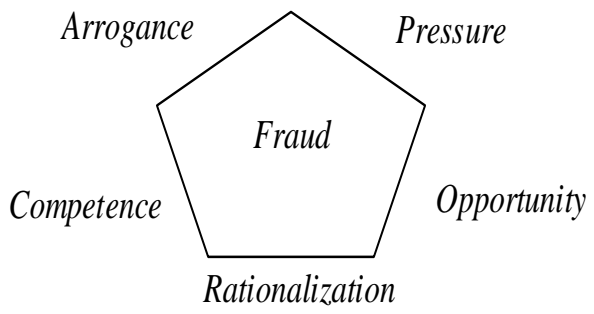

Gambar 1. Skema Fraud Pentagon Theory - Crowe Howarth (2011)

Dari gambar diatas dijelaskan bahwa terdapat lima alasan seseorang melakukan melakukan tindakan kecurangan (fraud) adalah pertama adanya tekanan (pressure) merupakan keinginan karyawan untuk berthindak fraud karena adanya tekanan dari pihak internal maupun eksternal Howarth (2011)

dalam (Pratiwi, 2018). Dalam Statement on Auditing Standard (SAS) No. 99, terdapat empat jenis kondisi umum yang terjadi pada tekanan yang dapat menyebabkan kondisi tersebut adalah :

a. Stabilitas keuangan (financial stability),

b. Tekanan eksternal (external pressure),

c. Kebutuhan keuangan pribadi (personal financial need), dan

d. Target keuangan (financial targets).

Kedua, kesempatan (opportunity) merupakan peluang yang dapat memungkinkan fraud itu terjadi disebabkan karena kurangnya pengawasan internal suatu perusahaan yang tidak efektif, maupun penyalahgunaan tugas dan tanggung jawab yang menyebabkan kesempatan ini menjadi peluang bagi pelaku untuk dapat melakukan tindakan kecurangan. Elemen ketiga fraud pentagon adalah rationalization yaitu perilaku atau sikap yang memperbolehkan seseorang untuk melakukan tindakan fraud dan mengangap tindakan yang dilakukan tidak salah.

Elemen keempat adalah competence, elemen ini disama artikan dengan kemampuan (capability) yang diutarakan dalam fraud diamond theory. Howarth (2011) menyebutkan bahwa kemampuan individu (individual competence) adalah sifat pribadi dan kemampuan yang memainkan peran utama sehingga, Elemen terakhir adalah arrogance yang di artikan sebagai sikap keserakahan dan superioritas dalam sebagian dirinya yang menganggap bahwa kebijakan dan prosedur organisasi tidak berlaku secara pribadi.

\subsection{Teori GONE}

Teori gone dikenalkan oleh Bologne (1993), yang merupakan penyempurnaan dari teori fraud triangle Cressey (1953). Pelaku kecurangan biasanya di dorong oleh dua faktor yaitu faktor internal dan eksternal dalam melakukan perbuatannya yang mana dalam teori ini dibagi menjadi empat komponen yaitu keserakahan (Greed), kesempatan (Opportunity), kebutuhan (Need), dan pengungkapan (Exposure). Kebutuhan dan keserakahan adalah faktor internal, sedangkan pengungkapan dan kesempatan yaitu merupakan faktor eksternal.

Berdasarkan teori gone, faktor internal seseorang melakukan kecurangan karena memang pada dasarnya manusia memiliki sifat serakah dan tak pernah merasa puas. Hal ini dapat terlihat dari banyaknya jumlah pelaku kecurangan yang berasal dari kalangan atas, yang dapat dikatakan bahwa mereka memiliki penghasilan yang besar dan kehidupan yang layak, namun tak pernah puas sehingga menghalalkan segala cara untuk memperoleh kekayaan yang lebih. Kebutuhan juga merupakan faktor internal yang muncul dari dalam diri individu pelaku kecurangan karena didesak oleh kebutuhan hidup 
yang semakin banyak.

Sedangkan faktor ekternal adalah kesempatan dan pengungkapan. Kesempatan adalah faktor dari luar individu atau yang berasal dari lingkungan sekitar pelaku sehingga menimbulkan adanya kesempatan bagi pelaku kecurangan untuk melakukan perbuatannya. Pengungkapan berkaitan dengan suatu tindakan atau konsekuensi yang dihadapi oleh pelaku fraud apabilan pelaku diketemukan melakukan kecurangan.

\subsection{Fraud}

Secara umum istilah fraud diartikan sebagai penipuan atau kecurangan dalam keuangan. Hall (2009) dalam Pratiwi (2018) menyatakan bahwa kecurangan (fraud) sebagai tindakan yang sengaja dilakukan agar dapat menimbulkan kerugian bagi pihak lain dan juga dapat memberikan keuntungan bagi pelaku kecurangan (fraud) atau kelompoknya. Hal ini senada dengan diungkapkan Sawyer (2006) dalam Pratiwi (2018) bahwa fraud adalah tindakan penipuan mencakup berbagai penyimpangan dan tindakan illegal yang ditandai dengan penipuan disengaja yang dilakukan oleh individu atau kelompok dengan tujuan untuk memperoleh keuntungan pribadi atau kelompoknya.

Ikatan Akuntansi Indonesia (IAI, 2001) mendefinisikan bahwa terjadinya kesalahan penyajian laporan keuangan dapat terjadi dalam dua bentuk, (1) Bentuk pertama adalah kesalahan penyajian karena kesalahan yang wajar dan hal itu bias merupakan tugas dari auditor untuk mengetahuinya. (2) Kesalahan dalam penyajian laporan keuangan dapat diketahui karena adanya kecurangan (fraud) dalam pelaporan keuangan dan juga kecurangan timbul dari perlakuan yang tidak semestinya terhadap aktiva. Aktiva dapat diganti nilainya dan dibuatkan laporan tidak sesuai dengan nilai yang benar sehingga agar bisa dicuri ataupun digelapkan. Maka dari beberapa definisi fraud yang telah dipaparkan sebelumnya diketahui bahwa fraud merupakan suatu tindakan kecurangan yang dilakukan dengan sengaja oleh pelakunya dengan melanggar ketentuan atau peraturan yang berlaku untuk mengambil keuntungan demi dirinya sendiri. Hal tersebut yang membedakan antara kecurangan dengan kesalahan.

\subsection{Kesesuaian Kompensasi}

Menurut Griffin (2004) dikutip dalam (Pratiwi, 2018), kompensasi adalah remunerasi financial yang diberikan oleh organisasi kepada karyawan sebagai bentuk pembayaran atas pekerjaan mereka. Sedangkan menurut pendapat Mathis dan Jackson (2001) dikutip dalam (Nababan, 2017) menyatakan kompensasi merupakan suatu cara manajemen untuk meningkatkan motivasi, prestasi kerja dan meningkatkan kinerja karyawan. Dengan kata lain, kompensasi adalah pengganti dari suatu hal dalam bentuk lainnya seperti gaji, bonus, maupun tunjangan-tunjangan yang dapat memberikan rasa keadilan tertentu pada seseorang. Umumnya tujuan pemberian kompensasi selain sebagai upaya dalam pemenuhan kebutuhan ekonomi pegawai, namun juga bertujuan untuk menunjukkan penghargaan dan perlakuan adil perusahaan terhadap pegawainya.

\subsection{Sistem Pengendalian Internal}

Menurut Committee of Sponsoring Organization (COSO) pengendalian internal merupakan sistem, proses atau struktur yang diimplemenkasikan oleh dewan komisaris, manajemen dan karyawan dalam perusahaan yang bertujuan untuk dapat menyediakan suatu jaminan yang memadai bahwa tujuan pengendalian tersebut dapat dicapai, meliputi efektivitas dan efisiensi operasi, keandalan pelaporan keuangan, dan juga ketaatan terhadap peraturan perundang-undangan. Senada dengan yang diungkapkan Mulyadi (2014) sistem pengendalian internal meliputi struktur organisasi, metode dan ukuran-ukuran yang dikoordinasikan untuk menjaga kekayaan organisasi, mengecek ketelitian dan juga keandalan data akuntansi, agar dapat mendorong efisiensi dan juga mendorong dipatuhinya kebijaksanaan manajemen.

\subsection{Pemanfaatan Teknologi Informasi}

Wilkinson, et al. (2000) mengungkapkan bahwa pemanfaatan teknologi informasi merupakan penggunaan secara optimal computer (mainframe, mini, micro), perangkat lunak (software), database, jaringan (internet), electronic commerce, dan jenis lainnya yang berhubungan dengan teknologi. 
Teknologi informasi berfungsi sebagai teknologi komunikasi untuk penyebaran informasi, juga berfungsi sebagai teknologi komunikasi untuk menghasilkan informasi yang berkualitas yaitu suatu informasi yang lebih akurat, relevan dan tepat waktu.

\subsection{Kompetensi}

Menurut Keputusan Kepala badan Kepegawaian Negeri Nomor: 46A tahun 2003 tentang pengertian kompetensi merupakan kemampuan dan karakteristik yang dimiliki oleh seorang Pegawai Negeri Sipil yaitu berupa keterampilan, pengetahuan, dan juga sikap perilaku yang diperlukan dalam pelaksanaan tugas jabatannya, sehingga Pegawai Negeri Sipil dapat melaksanakan tugasnya secara professional, efektif dan efisien. Lebih jelasnya lagi, Wibowo (2010:324) dalam (Hamdani, 2017) mengemukan bahwa kompetensi merupakan suatu kemampuan untuk dapat melaksanakan atau melakukan suatu pekerjaan yang dilandasi atas keterampilan.

\subsection{Budaya Etis Organisasi}

Budaya etis organisasi adalah sistem nilai, norma dan kepercayaan yang bersama-sama dimiliki oleh masing-masing anggota organisasi yang kemudian mempengaruhi cara bekerja dan berperilaku dari setiap para anggota organisasi agar terciptanya perilaku yang baik dan beretika serta menghindari suatu tindakan-tindakan yang dapat merugikan organisasi, sehingga tindak kecurangan pada suatu organisasi

akan sulit akan sulit terjadi (Parmawan, et al., 2017) dalam (Pratiwi, 2018). Menurut Robins (2013) budaya etis organisasi merupakan suatu presepsi yang dianut oleh anggota-anggota suatu instansi atau organisasi, sehingga presepsi tersebut menjadi suatu sistem dan makna bersama yang dianut para anggotanya.

\subsection{Model Penelitian}

Model penelitian ini akan menjelaskan bahwa fraud dipengaruhi empat faktor yaitu kesesuaian kompensasi, sistem pengendalian internal, pemanfaatan teknologi informasi dan kompetensi. Empat faktor tersebut dimoderasi oleh faktor budaya etis organisasi. Model penelitian dapat dijelaskan secara sederhana, melalui gambar dibawah ini:

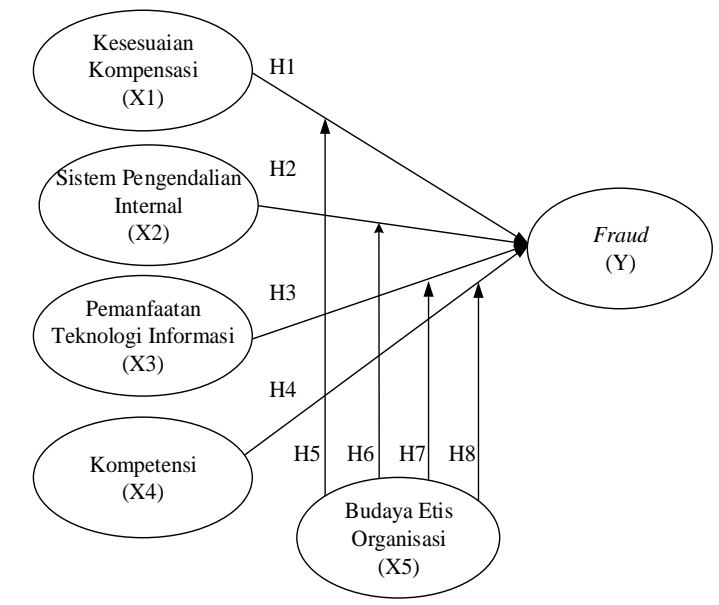

Gambar 2. Model Penelitian (Sumber: Penulis, 2019)

\subsection{Pengembangan Hipotesis}

H1 : Kesesuaian kompensasi berpengaruh terhadap fraud

H2 : Sistem Pengendalian Internal berpengaruh terhadap Fraud

H3 : Pemanfaatan Teknologi Informasi berpengaruh terhadap Fraud

H4 : Kompetensi berpengaruh terhadap Fraud

H5 : Budaya Etis Organisasi Memoderasi Pengaruh Kesesuaian Kompensasi terhadap Fraud

H6 : Budaya Etis Organisasi Memoderasi Pengaruh Sistem Pengendalian Internal terhadap Fraud

H7 : Budaya Etis Organisasi Memoderasi Pengaruh Pemanfaatan Teknologi Informasi terhadap Fraud 
H8 : Budaya Etis Organisasi Memoderasi Pengaruh Kompetensi terhadap Fraud

\section{Metode Penelitian}

3.1 Lokasi Penelitian

Penelitian ini dilakukan di Organisasi Perangkat Daerah (OPD) Pemerintah Kota Jayapura.

\subsection{Populasi dan Sampel}

Populasi adalah wilayah generalisasi yang terdiri atas objek atau subjek yang mempunyai kausalitas dan karakteristik tertentu yang ditetapkan oleh peneliti untuk dapat dipelajari dan kemudian ditarik kesimpulannya. Dalam penelitian ini populasinya adalah pegawai yang bekerja di Organisasi Perangkat Daerah (OPD) Pemerintah Kota Jayapura.

Metode penelitian sampel dalam penelitian ini dengan menggunakan teknik Cluster Sampling. Cluster Sampling merupakan sebuah teknik sampel yang terdiri dari kelompok-kelompok individu unit yang kecil. Dalam penelitian ini yang menjadi sampel adalah Kepala OPD, Staf Keuangan dan Pengelola Keuangan.

\subsection{Jenis Penelitian dan Sumber Data}

Jenis penelitian ini menggunakan data kuantitatif yaitu data yang berbentuk angka atau bilangan, dan sumber data diambil dari data primer yaitu data yang diperoleh langsung dari sumber di lapangan oleh peneliti di jadikan sebagai objek penelitian.

Sumber data pada penelitian ini berasal dari data primer, yaitu dengan menyebarkan kuesioner secara langsung kepada responden yang menjadi objek penelitian untuk diperoleh jawaban yang akan digunakan untuk analisis data.

\subsection{Metode Pengumpulan Data}

Metode pengumpulan data dalam penelitian ini menggunakan angket atau kuesioner. Kuesioner dari penelitian ini terdiri dari dua bagian utama. Bagian pertama terdiri dari identitas diri yang menggambarkan karakteriristik responden. Bagian kedua berisi serangkaian pertanyaan untuk mengukur variabel-variabel penelitian. Pengumpulan data dilakukan dengan metode distribusi langsung, yaitu dengan mendatangi para responden secara langsung untuk menyerahkan kuesioner maupun mengumpulkan kembali kuesioner.

\section{Hasil Dan Pembahasan}

\subsection{Uji Validitas}

Uji validitas ini dilakukan dengan melihat nilai AVE dan Loading factor pada output PLS. Berdasarkan nilai Output Combined Loading and Cross-Loading diperoleh hasil bahwa hampir semua indikator telah memiliki nilai loading factor > 0,7. Indikator K5 dan BEO4 dan BEO5 menunjukkan nilai loading factor di bawah dari 0,5 sehingga harus dikeluarkan atau dihapuskan dari model. Menurut Hartono dan Abdillah (2009), indikator dengan nilai AVE lebih dari 0,5 sebaiknya tidak dikeluarkan atau dihapus dari konstruk tersebut. Berikut hasil output yang dihapus dari model:

Nilai AVE setiap konstruk sudah menunjukkan nilai di atas 0,5 kecuali untuk konstruk Budaya Etis Organisasi yang memiliki nilai AVE 0,451 < 0,5. Hal ini bahwa dalam konstruk Budaya Etis Organisasi, terdapat indikator yang tidak masuk dalam konstruk tersebut. Penghapusan indikator yang tidak memenuhi kriteria dari kontruk BEO diharapkan meningkatkan nilai AVE. Hal ini dapat dilihat dari hasil pengujian sesudah koreksi dilakukan.

Berdasarkan hasil pengujian kembali untuk melihat nilai loading factor setelah dilakukan penghapusan atas beberapa indikator yaitu BEO4, BEO5, dan K5 dari model, maka di peroleh hasil bahwa seluruh indikator penelitian telah memiliki nilai loading factor $>0,5$ dan juga telah mengumpul pada masing-masing konstruk yang sebenarnya. Pengukuran selanjutnya adalah melihat nilai AVE, bahwa AVE yang digunakan untuk evaluasi validitas konvergen, kriteria yang harus dipenuhi yaitu AVE > 0,5. Berikut ini nilai AVE setelah penghapusan indikator: 
Setelah dilakukannya penghapusan indikator BEO4, BEO5, dan K5, maka dapat dilihat dari tabel di atas bahwa nilai AVE dari konstruk Budaya Etis Organisasi yang semula tidak memenuhi syarat validitas konvergen, setelah dilakukan pengolahan data ulang dengan mengeluarkan tiga indikator, telah mengalami peningkatan yang semula 0,451 menjadi 0,651 dan variabel lainnya juga memiliki nilai AVE > 0,5. Dengan demikian jika dilihat dari nilai AVE dapat disimpulkan bahwa konstruk tersebut telah valid.

\subsection{Uji Reliabilitas}

Untuk Uji Reabilitas dapat dilihat dari nilai Cronbach's Alpha dan Composite Reliability dan membandingkan dengan Rule of Tumb, yaitu nilai Cronbach's Alpha dan Composite Reliability harus memiliki nilai di atas 0,7 sehingga konstruk dapat memenuhi uji reliabilitas.

Tabel 1. Composite Reliability dan Cronbach's Alpha

\begin{tabular}{lccc}
\hline \multicolumn{1}{c}{ Variabel } & $\begin{array}{c}\text { Composite } \\
\text { Reliability }\end{array}$ & $\begin{array}{c}\text { Cronbatch' } \\
\text { s Aplha }\end{array}$ & Keterangan \\
\hline Kesesuaian Kompensasi & 0,889 & 0,848 & Reliabel \\
Sistem Pengendalian Internal & 0,948 & 0,935 & Reliabel \\
Pemanfaatan Teknologi Informasi & 0,899 & 0,849 & Reliabel \\
Kompetensi & 0,895 & 0,852 & Reliabel \\
Budaya Etis Organisasi & 0,848 & 0,732 & Reliabel \\
Fraud & 0,945 & 0,928 & Reliabel \\
\hline
\end{tabular}

Sumber: Data diolah, 2019

Berdasarkan tabel diatas menunjukkan bahwa setiap konstruk telah memenuhi syarat parameter Cronbanch's Alpha dan Composite Reliability dengan nilai di atas 0,7 sehingga dapat diketahui bahwa konstruk tersebut dinyatakan reliabel.

\subsection{Evaluasi Model Struktural (Inner Model)}

Tahap berikutnya melakukan evaluasi struktural (Inner Model) dengan melihat besarnya presentase variance yang dijelaskan dengan melihat nilai adjusted R-squared untuk setiap variabel laten dependen sebagai prediksi dari model struktural kemudian tahap selanjutnya yaitu test untuk menguji $Q^{2}$ predictive relevance dan Goodness of Fit (GOF).

Selanjutnya dilakukan uji inner model dengan melihat nilai adj.R-squared dimana nilai adj.Rsquared pada variabel fraud (kecurangan), menunjukkan nilai 0,294 yang berarti bahwa,variabel kesesuaian kompensasi, sistem pengendalian internal, pemanfaatan teknologi informasi, kompetensi dan budaya etis organisasi sebesar $29,4 \%$ dan sisanya $70,6 \%$ dijelaskan oleh variabel lain yang tidak ada dalam penelitian ini atau faktor lain yang tidak ada pada model.

Selain melihat dengan nilai R-squared, suatu model dikatakan nilai predictive relevance jika Qsquared $>0$, nilai $Q^{2}$ predictive relevance kecurangan (fraud) menunjukkan nilai $0,418>0$ yang berarti bahwa model memiliki nilai predictive relevance.

\subsection{Pembahasan Hasil Pengujian Hipotesis}

Pengujian hipotesis dimaksudkan untuk memberikan kebenaran dugaan penelitian atau hipotesis. Hasil korelasi antar konstruk diukur dengan melihat path coefficients dan tingkat signifikansinya. Tingkat signifikansi yang dipakai dalam penelitian ini adalah 5\% $(0,05)$, hipotesis akan diterima jika nilai $\mathrm{P}<0,05$. Hasil output model WarpPLS 7.0 adalah sebagai berikut: 


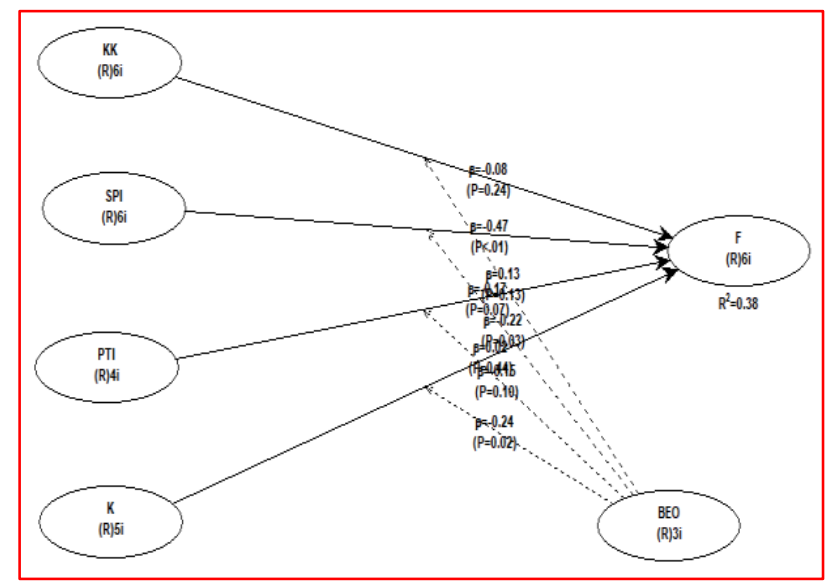

Gambar 3. Hasil Output Model Warp PLS 7.0 (Sumber: Data diolah, 2019)

Terdapat 3 hipotesis yang didukung dan 5 hipotesis lainnya ditolak, karena nilai $p$ value pada setiap hipotesis tersebut lebih dari kriteria yang ditetapkan yaitu $<0,05$. Berikut dijabarkan hasil output path coefficient untuk uji signifikansi $p$ value $(<0,05)$.

\subsubsection{Uji Hipotesis 1 (H1) Pengaruh Kesesuaian Kompensasi terhadap Fraud}

Hasil pengujian menunjukkan bahwa H1: ditolak sehingga dapat dikatakan bahwa kesesuaian kompensasi tidak memiliki pengaruh terhadap kecurangan (fraud). Hasil penelitian ini tidak sejalan dengan penelitian Thoyibatun (2012) yang menyatakan bahwa dengan adanya kesesuaian kompensasi yang dikaitkan pada kinerja karyawan memberikan pengaruh terhadap penurunan tindakan dalam melakukan kecurangan (fraud). Namun sejalan dengan penelitian Pratiwi (2018) yang menyatakan bahwa konstruk keseusaian kompensasi tidak mempunyai pengaruh terhadap kecurangan.

Ketika dalam penelitian lain kompenasi dapat menurunkan tingkat kecurangan dan meningkatkan kinerja pegawai, dalam penelitian ini hasil yang diperoleh berbeda. Hal ini dapat dilihat dari data deskriptif, dimana rata-rata menjawab kompensasi yang diperoleh selama ini telah sesuai yang artinya keadaan itu akan menurunkan tingkat kecurangan dalam instansi. Namun, hasil pengujian menunjukkan hasil yang sebaliknya, karena sesuai dan tidak sesuainya kompenasi yang diterima tidak dapat mempengaruhi seseorang untuk melakukan tindakan kecurangan (fraud).

\subsubsection{Uji Hipotesis 2 (H2) Pengaruh Sistem Pengendalian Internal terhadap Fraud}

Hasil pengujian menunjukkan $\mathbf{H 2}$ : diterima sehingga dapat dikatakan bahwa sistem pengendalian internal memiliki pengaruh negatif dan signifikan terhadap kecurangan (fraud). Hal ini berarti bahwa kecurangan dapat dikurangi jika sistem pengendalian internal yang efektif diterapkan dalam perusahaan. Semakin tinggi sistem pengendalian internal maka semakin rendah tingkat keterjadiannya kecurangan (fraud) dalam instansi. Jadi, hal tersebut dapat mengindikasikan bahwa jika pimpinan dan staf akuntansi dapat menerapkan sistem pengendalian yang efektif dalam instansi akan mencegah tindakan kecurangan (fraud).

Penelitian ini sejalan dengan peneliti sebelumnya dari Pratiwi (2018) yang menyatakan bahwa sistem pengendalian internal berpengaruh negatif terhadap terjadinya fraud. Jadi, apabila semakin baik sistem pengendalian internal maka tindakan untuk melakukan kecurangan (fraud) akan semakin rendah. Hasil penelitian ini sejalan juga dengan penelitian Wilopo (2008) bahwa suatu pengendalian internal cenderung akan efektif untuk menekan praktek-praktek kecurangan (fraud) akuntansi. Dan juga, hasil dari peneltian Syahadat \& Damayanti (2017) dalam (Salle, 2018) yang menyatakan bahwa suatu pengendalian internal berpengaruh negatif terhadap kecurangan.

\subsubsection{Uji Hipotesis 3 (H3) Pemanfaatan Teknologi Informasi terhadap Fraud}

Hasil pengujian menunjukkan $\mathbf{H 3}$ : ditolak dapat dikatakan bahwa pemanfaatan teknologi informasi tidak berpengaruh terhadap fraud. Hasil penelitian ini tidak sejalan dengan penelitian Pratiwi (2018), Hersi Huslina, Islahuddin (2015) dan Maharsi (2000:141) yang menyatakan bahwa 
pemanfaatan teknologi informasi memiliki pengaruh signifikan terhadap kecurangan (fraud). Dari hasil data deskriptif rata-rata responden setuju dengan adanya pemanfaatan teknologi informasi karena, dengan pemanfaatan teknologi informasi akan sangat membantu dalam mempercepat penyajian laporan keuangan dan pengolahan data transaksi agar dapat menekan tingkat kecurangan (fraud).

Sebaliknya, jika tanpa pemanfaatan teknologi informasi yang baik maka kecurangan akan meningkat. Hal ini sangat penting apabila suatu sistem rusak dan gagal, instansi dapat menjadi lumpuh akibat ketidakmampuan untuk mendapatkan kembali informasi yang hilang atau karena penggunaan informasi yang tidak andal, yang disebabkan oleh kesalahan dalam pemrosesannya (Korompis, 2015). Namun, hasil pengujian menunjukkan hasil yang berbeda karena pemanfaatan teknologi informasi tidak berpengaruh terhadap kecurangan ( fraud).

\subsubsection{Uji Hipotesis 4 (H4) Pengaruh Kompetensi terhadap Fraud}

Hasil pengujian menunjukkan H4 : ditolak dapat diketahui bahwa kompetensi tidak memiliki pengaruh terhadap kecurangan ( fraud). Hal ini tidak sejalan dengan penelitian yang dilakukan oleh Pratomo, et al, (2016) dalam (Pratiwi, 2018) yang menyatakan bahwa kompetensi memiliki pengaruh terhadap tindakan fraud.

Menurut studi ACFE, Report to the Nation yang menyatakan bahwa perilaku kecurangan (fraud) memiliki tingkat pendidikan yang tinggi. Jadi, ketika kompetensi seseorang dapat mampu memahami kelemahan suatu sistem yang ada, maka pada titik inilah godaan untuk melakukan kecurangan (fraud) muncul dengan kecerdasan dan kreativitasnya seseorang akan dapat menembus sistem pengendalian internal untuk mengambil keuntungan pribadi. Namun, sebaliknya jika seorang pegawai mempunyai pengetahuan atau kompetensi yang baik dan memiliki pengaruh budaya atau lingkungan yang positif yang taat terhadap peraturan yang sudah diterapkan di dalam instansi, serta di tanamkannya nilai-nilai yang religius terhadap apa yang telah dikerjakan memiliki dampak baik atau buruk. Jadi, hal tersebut dapat memotivasi seseorang untuk tidak melakukan tindakan kecurangan sehingga terciptanya lingkungan kerja atau budaya yang baik serta menjunjung tinggi nilai-nilai dan norma agar dapat tercapai tujuan dari instansi tersebut.

\subsubsection{Uji Hipotesis 5 (H5) Budaya Etis Organisasi Memoderasi Pengaruh Kesesuaian Kompensasi terhadap Fraud}

Hasil pengujian menunjukkan H5 : ditolak bahwa budaya etis organisasi tidak memiliki pengaruh sebagai variabel moderasi kesesuaian kompensasi terhadap fraud. Hal ini dapat dilihat dari nilai signifikasinya sebesar 0,130 lebih besar dari 0,05 atau 5\%. Hal tersebut tidak sejalan dengan penelitian Pratiwi (2018) yang menyatakan bahwa budaya etis organisasi memiliki pengaruh negatif terhadap fraud. Kondisi tersebut bisa terjadi perbedaan dengan penelitian ini.

Memiliki nilai, norma dan kepercayaan dalam organisasi dapat mempengaruhi cara berperilaku seseorang. Sehingga, apabila budaya dalam seuatu organisasi tersebut baik maka seseorang yang memiliki kompensasi atau gaji yang tinggi maupun rendah tidak akan melakukan tindakan kecurangan. Namun, sebaliknya jika budaya dalam organisasi itu tidak memiliki nilai, norma dan kepercayaan maka dapat terciptanya lingkungan kerja yang berperilaku menyimpang. Seseorang yang berperilaku menyimpang karena adanya lingkungan kerja yang tidak mematuhi peraturan atau terdapat ketidak adilan dalam pemberian kompensasi kepada setiap pegawai. Sehingga, pegawai yang merasa kompensasi yang diberikan tidak sesuai, maka kemungkinan akan melakukan tindakan kecurangan (fraud).

\subsubsection{Uji Hipotesis 6 (H6) Budaya Etis Organisasi Memoderasi Pengaruh Sistem Pengendalian Internal terhadap Fraud}

Hasil pengujian H6 : diterima sehingga menunjukkan bahwa budaya etis organisasi memperlemah pengaruh sistem pengendalian internal terhadap fraud. Hasil analisis dapat dilihat dari nilai signifikansinya sebesar 0,025 lebih kecil dari 0,05 atau 5\%. Berdasarkan hasil analisis menunjukkan bahwa interaksi budaya etis organisasi dan sistem pengendalian internal berpengaruh terhadap kecurangan (fraud). 


\subsubsection{Uji Hipotesis 7 (H7) Budaya Etis Organisasi Memoderasi Pengaruh Pemanfaatan Teknologi Informasi terhadap Fraud}

Hasil pengujian $\mathbf{H 7}$ : ditolak ini menunjukkan bahwa budaya etis organisasi tidak memiliki pengaruh sebagai variabel moderasi pemanfaatan teknologi informasi terhadap fraud. Hasil analisis dapat dilihat dari nilai signifikansinya sebesar 0,099 lebih besar dari 0.05 atau 5\%. Berdasarkan hasil analisis menunjukkan bahwa interaksi antara budaya etis orgnisasi dan pemanfaatan teknologi informasi tidak berpengaruh terhadap fraud.

Budaya dalam instansi dapat mempengaruhi setiap pegawai, agar terciptanya perilaku baik dan beretika sehingga terhindar dari tindakan-tindakan yang merugikan instansi. Jadi, dengan adanya pemanfaatan teknologi informasi akan sangat membantu dalam mempercepat proses pengolahan data transaksi dan penyajian laporan keuangan. Kemudian, apabila seorang pegawai mengalami tekanan atau dilema-dilema etis dari lingkungan instansi akan memungkinkan menjadi pemicu seseorang menyalahgunakan informasi tersebut untuk kepentingan pribadinya. Seseorang yang memanfaatkan teknologi informasi yang berpegang teguh dengan nilai-nilai dalam budaya etis dapat menghasilkan laporan keuangan dan pertanggung jawaban yang jelas.

\subsubsection{Uji Hipotesis 8 (H8) Budaya Etis Organisasi Memoderasi Pengaruh Kompetensi terhadap Fraud}

Hasil pengujian $\mathbf{H 8}$ : diterima hal ini menunjukkan bahwa budaya etis organisasi memperlemah pengaruh kompetensi terhadap fraud. Hasil analisis dapat dilihat dari nilai signifikansinya sebesar 0,018 lebih kecil dari 0,05 atau 5\%. Berdasarkan hasil analisis menunjukkan bahwa interaksi budaya etis organisasi dan kompetensi berpengaruh terhadap kecurangan (fraud). Penelitian ini sejalan dengan penelitian Siregar \& Hamdani (2018) yang menyatakan bahwa budaya etis organisasi berpengaruh terhadap fraud. Dalam kondisi ini, semakin tingginya nilai budaya etis yang diterapkan maka akan dapat menurunkan terjadinya fraud. Adapun dalam penelitiannya menyatakan bahwa kompetensi tidak berpengaruh signifikan terhadap fraud.

\subsubsection{Uji Tambahan (Uji Beda - Independent Sample T-Test)}

Dalam peneltian ini, menggunakan uji beda independent sample t-test yang merupakan bagian dari statistic inferensial parametic (Uji Beda). Dengan dasar pengembalian keputusan adalah sebagai berikut:

1. Jika nilai Sig (2-tailed) $>0,05$ maka tidak terdapat perbedaan yang signifikan antara Pengelola Keuangan dan Kepala.

2. Jika nilai Sig (2-tailed) $<0,05$ maka terdapat perbedaan yang signifikan antara Pengelola Keuangan dan Kepala.

\subsubsection{Uji Beda Variabel Fraud antara Pengelola Keuangan dan Kepala di Organisasi Perangkat Daerah (OPD)}

Berikut tabel dibawah ini adalah hasil pengujian uji beda Independent Sample T-test yang dapat dilihat dari bagian sigifikansi (2-tailed). Variabel yang digunakan dalam pengujian sampel adalah kecurangan (fraud).

Data tabel diatas dapat dilihat bahwa nilai signifikansinya $>0,5$ maka tidak terdapat perbedaan yang signifikan dari Pengelola Keuangan yang sebesar 0,361 atau 36\% kemudian, untuk Kepala sebesar 0,380 atau 38\%. Dengan demikian, peneliti dapat menyimpulkan bahwa antara pengelola keuangan dan kepala tidak terdapat perbedaan dalam melakukan tindakan kecurangan.

Hal ini sejalan, dengan berdasarkan data deskriptif variabel kecurangan (fraud) dapat diketahui bahwa jumlah responden dalam menjawab kuesioner lebih mengarah ke jawaban yang tidak setuju dalam pernyataan pertama yaitu instansi pernah mencatat tanggal transaksi yang tidak sesuai dengan waktu transaksi yang sebenarnya. Sehingga, dapat disimpulkan kembali bahwa antara pengelola keuangan dan kepala sama-sama memiliki komitmen serta tujuan yang sama di dalam instansi sehingga tindakan untuk melakukan kecurangan ( fraud) tidak terjadi. 


\section{Penutup}

\subsection{Kesimpulan}

Berdasarkan rumusan masalah, tujuan penelitian, landasan teori, hipotesis, dan hasil penelitian, dapat disimpulkan bahwa: 1) kesesuaian kompensasi tidak berpengaruh terhadap kecurangan (fraud) pada pemerintah Kota Jayapura, 2) sistem pengendalian internal berpengaruh negatif terhadap kecurangan (fraud) pada pemerintahan Kota Jayapura, 3) pemanfaatan teknologi informasi tidak berpengaruh terhadap kecurangan (fraud) pada pemerintah Kota Jayapura, 4) kompetensi tidak berpengaruh terhadap kecurangan (fraud) pada pemerintah Kota Jayapura, 5) budaya etis organisasi tidak memoderasi kesesuaian kompensasi terhadap fraud, 6) budaya etis organisasi memoderasi sistem pengendalian internal terhadap fraud, 7) budaya etis organisasi tidak memoderasi pemanfaatan teknologi informasi terhadap fraud, dan 8) budaya etis organisasi memoderasi kompetensi terhadap fraud.

\subsection{Keterbatasan Penelitian}

Penelitian yang dilakukan saat ini masih memiliki banyak kekurangan dan keterbatasan, di antaranya adalah sebagai berikut:

1. Penelitian ini dilaksanakan bertepatan dengan adanya pandemi global yaitu wabah Covid-19, sehingga dilakukan pembatasan sosial berskala besar (PSBB) di pemerintah Kota jayapura dengan pembatasan aktivitas hingga pada pukul 14.00 WIT. Sebelumnya peneliti menggunakan kuesioner online hanya saja tidak efektif dalam penyebarannya maka, peneliti memutuskan untuk menggunakan kuesioner secara manual.

2. Data pada penelitian ini diambil hanya berdasarkan survey yang diisi oleh responden dan tidak melakukan wawancara langsung dengan responden sehingga ada beberapa jawaban responden yang terkadang tidak sesuai dengan yang seharusnya.

3. Variabel penelitian yang digunakan hanya dapat menjelaskan $29,4 \%$ dan sisanya $70,6 \%$ dijelaskan oleh variabel lain yang tidak ada pada penelitian.

4. Pada variabel kesesuaian kompensasi tidak terdapat keterangan lebih lanjut tentang kompensasi yang dimaksud sama dengan Tambahan Penghasilan Pegawai (TPP) yang artinya bahwa pembayaran gaji pegawai berdasarkan kehadiran dan kinerja.

\subsection{Saran}

Berdasarkan kesimpulan hasil dan keterbatasan penelitian, dapat disampaikan beberapa saran sebagai berikut:

1. Bagi peneliti/akademis

a. Bagi peneliti selanjutnya agar mengembangkan penelitian ini dengan menambah jumlah populasi dan sampel, dan juga memperluas ruang lingkup penelitian.

b. Diharapkan untuk peneliti selanjutnya dapat melakukan revisi kembali terhadap butir pernyataan pada penelitian ini agar dapat meningkatkan kualitas data yang diperoleh.

c. Penelitian selanjutnya disarankan menggunakan variabel lain yang berpengaruh lebih kuat terhadap fraud di sktor pemerintah.

2. Bagi Pihak Pemerintah

a. Pemerintah dapat lebih efektif dalam pencegahan dan pembatasan fraud atau korupsi dengan dilakukan analisa moderasi dengan menggunakan variabel lain sehingga dapat diketahui faktor apa saja yang dapat mempengaruhi terjadinya fraud atau korupsi.

b. Di harapkan dapat meningkatkan ketaatan peraturan yang telah dibuat. Serta lebih memperbaiki diri dan niat dalam bekerja agar peluang untuk melakukan kecurangan atau korupsi dapat dihindari.

\section{Daftar Pustaka}

Adelin, V. (2013). "Pengaruh Pengendalian Internal, Ketaatan Aturan Akuntansu, dan Perilaku Tidak Etis Terhadap Kecenderungan Kecurangan Akuntansi (Studi Pada BUMN di Kota Padang). (September).

Adinda, Y. M. (2015). Faktor yang mempengaruhi terjadinya kecurangan ( fraud) di sektor 
pemerintahan kabupaten klaten.

Arles, L. (2014). "Faktor - Faktor Pendorong Terjadinya Fraud: Predator vs. Accidental Fraudster Diamond theory Refleksi Teori Fraud Triangle (Klasik) Suatu Kajian Teoritis.” 1-15.

Association of Certified Fraud Examiners, I. C. (2017). "Association of Certified Fraud Examiners." Association of Certified Fraud Examiners, 111(Chapter), 1-62.

Cooper, B. J. (2015). Modern Auditing \& Assurance Services.

COSO. (2013). 2013 COSO Framework - Overview and Considerations. (June).

Fajarina, Wirda, D. dan A. B. U. (2012). "Pengaruh Lingkungan Pengendalian, Penilaian Risiko, Kegiatan Pengendalian, Informasi dan Komunikasi, Serta Pemantauan Terhadap Pencegahan Fraud Pengadaan Barang/Jasa Pada SKPD di Pemerintah Aceh.” Jurnal Akuntansi Pascasarjana Universitas Syiah Kuala, Vol.1 No.1.

Hamdani, M. (2017). "Pengaruh Kesesuaian Kompensasi, Keefektifan Organisasi, dan Kompetensi Terhadap Fraud ( Studi pada Satuan Kerja Vertikal Kementerian Keuangan Provinsi Lampung ).”

Hersi Huslina, Islahuddin, N. S. (2015). "Pengaruh integritas Aparatur, Kompetensi Aparatur, dan Pemanfaatan Teknologi Informasi terhadap Efektivitas Sistem Pencegahan Fraud.” 4(1), 55-64.

Howarth. (2011). Crowe's fraud pentagon theory dalam pencegahan fraud pada proses pengadaan melalui e-procurement. 1(2), 161-171.

IAI. (2001). SA Seksi 316. 312(70).

Kaltengpos.co. (n.d.). "Tersangka Kasus Korupsi Proyek Jalan di Papua Segera Jalani Sidang." Retrieved from http://www.kaltengpos.co/berita/-34284tersangka_kasus_korupsi_proyek_jalan_di_papua_segera_jalani_sidang.html

Karmita, F. (2015). "Pengaruh Pemanfaatan Teknologi Informasi dan Kompetensi Sumber Daya Manusia terhadap Efektivitas Sistem Informasi Akuntansi." In Skripsi.

Kholida Atiyatul Maula. (2017). "Analisis Pengaruh Faktor- Faktor Pendorong Tindak Kecurangan terhadap Kecendrungan Aparatur Pemerintah Melakukan Fraud (Persepsi Pegawai Dinas Kabupaten Banyumas) Kholida." 2(01), 273-287.

Korompis, C. W. M. (2015). Dampak Teknologi Informasi Dalam Pengendalian Internal untuk Mengantisipasi Kecenderungan Kecurangan Akuntansi. 27-33.

Larassati, P. (2017). "Pengaruh Pemanfaatan Teknologi Informasi Pengawasan Keuangan Sumber Daaya Manusia dan Pengendalian Intern Terhadap Keterandalan Pelaporan Keuangan Pemerintah Daerah." 4(1).

Latrini, P. A. P. E. P. dan M. Y. (2018). "Pengaruh pengendalian Internal, Budaya Organisasi, Dan Moralitas Pada Kecenderungan Kecurangan (Fraud) Di Lpd Se-Kabupaten Gianyar.” 25, 21552184.

Lestaluhu, J. A. (2017). Pengaruh Environmental Performance Dan Environmental Disclosure Terhadap Economic Performance.

Maharsi, S. (2000). Pengaruh Perkembangan Teknologi Informasi Terhadap Bidang Akuntansi Manajemen. Jurnal Akuntansi Dan Keuangan, 2(2), 127-137. https://doi.org/10.9744/jak.2.2.pp.127-137

Mudzakkir. (2005). "Pemberantasan Korupsi." Retrieved from https://www.bphn.go.id/data/documents/kpd-2011-7.pdf

Nababan, D. (2017). Pengaruh Motivasi Kerja dan Kompensasi Sebagai Variabel Moderating. XXI(02), 306-316.

Pratiwi, T. (2018). "Pengaruh Kesesuaian Kompensasi, Sistem Pengendalian Internal, Pemanfaatan Teknologi Informasi, Budaya Etis Organisasi dan Kompetensi Terhadap Fraud Pada Pemerintah Daerah." 
Rae, K., \& Subramaniam, N. (2008). Quality of internal control procedures: Antecedents and moderating effect on organisational justice and employee fraud. Managerial Auditing Journal, 23(2), 104-124. https://doi.org/10.1108/02686900810839820 